\title{
THE RELATIONSHIP BETWEEN NATIONAL IDENTITY, SUBJECTIVE WELL-BEING AND MEANING IN LIFE
}

\author{
Eli Grozdanovska \\ Georgi Dimitrov 66/1-8 \\ 1000 Skopje, Macedonia \\ eli.grozdanovska@gmail.com
}

\begin{abstract}
Studies have shown a strong relationship between national identity and some of the constructs of positive psychology. So far, these topics have rarely been researched in the Macedonian context. The purpose of this study was to examine the relationship between national identity, subjective well-being and meaning in life. Thus, 204 undergraduate students participated in the study, 146 female and 58 male students at the age of 18 to 23 years. The data was acquired with the following four scales: national identity was measured with The National Identity Scale (NIS); the meaning in life was measured with the Meaning in Life Questionnaire (MIQ); the cognitive aspect of subjective well-being was measured with the Satisfaction With Life Scale (SWLS); and the affective aspect was measured with the Positive and Negative Affect Schedule (PANAS). It has been hypothesized that the students with higher national identity would have higher satisfaction with life, more positive affects and higher meaning in life; contrary to the students with lower national identity who would have lower satisfaction with life, more negative affects and lower meaning in life. The relationships between each dimension were estimated with the Pearson Product Moment Correlation Coefficient, and the results partially confirmed the predictions. Positive significant correlation was found between national identity, satisfaction with life and the presence of meaning in life. No significant relationship was found between national identity and the affective (positive and negative) aspects of subjective well-being. These findings are important because they provide a new insight into the relationship between the construct of national identity and the constructs of positive psychology, meaning in life and the aspects of subjective well-being.
\end{abstract}

Key words: national identity, subjective well-being, meaning in life

\section{INTRODUCTION}

People live in groups and they are defined by the groups they live in. Although most people are members of many different groups, only few are meaningful in 
terms of how they define us. One of the groups in which we live is the nation. For many people national identity is the central element of self-determination and it becomes an important social identity (Deaux, 2001). There are many reasons that confirm the concept of national identity to be a highly relevant socio-psychological phenomenon. But, the question of national identity itself has been relatively rarely examined by psychologists even though it is highly relevant for conceptualizing a very popular theme of group belonging and social identity. Generally, national identity applies to citizens of a nation-state. According to Smith (1992), national identity is multidimensional and involves historical territory, common memories and myths of origin, mass, standardized public culture, common economy and territorial mobility, common legal rights and duties. The psychological dimension of national identity arises from the consciousness of forming a group based on the closeness that is felt uniting those who belong to the nation (Guibernau, 2004). According to Connor, sharing a national identity generates an emotional bond among fellow nationals, which is fundamentally psychological and non-rational (as cited at Guibernau, 2004). The social identity theory asserts that group membership creates an in-group self-categorization and enhancement in ways that favor the in-group at the expense of the out-group. According to this perspective (Brewer, 1993), categorization of social objects into distinct groups produces accentuation of intergroup differences and intragroup similarities. Tajfel and Turner (1986) showed that the act of individuals categorizing themselves as group members is sufficient to lead them to display in-group favoritism. Individuals seek to achieve positive self-esteem by positively differentiating their group when compared to another group, based on some valued dimension. This quest for positive distinctiveness means that people's sense of who they are is defined in terms of 'we' rather than 'I'. Through this identification with the nation the individuals transcend their finite and, at least for some, meaningless lives. Their efforts and sacrifices become worthwhile, even heroic, and the conviction of having contributed to a higher aim, that of preserving and enhancing the nation, increases the individuals' self-esteem (Guibernau, 2004).

Since ancient times humans have wondered what is the ingredient of having a happy life. Nowadays, the broad concept of subjective well-being suggests that it includes experiencing pleasant emotions, low levels of negative moods, and high life satisfaction (Diener, Lucas \& Oishi, 2002). Thus, a viable theory of happiness must, first, recognize the importance of adaptation. In addition to adaptation as the first component, comes the second which is cultural worldview. Cultural templates for interpreting life events predispose varying subjective well-being in the absence of differing objective life circumstances. Furthermore, the third component is values and goals. So, who is happy? Knowing the person's age, sex, race and income hardly gives any clues. Better clues come from knowing the person's traits, whether the person enjoys a supportive network of close friends, whether the person's culture offers positive interpretations of most of the daily events, whether the person 
is engaged by work and leisure and whether the person has faith that entails social support, purpose and hope (Myers \& Diener, 1995).

Historically, one of humanity's concerns has been to create institutions, rituals, and beliefs that give life a sense of purpose, predictability, and comprehensibility (Steger, 2009b). People experience the presence of meaning in life when they comprehend themselves and the world, when they understand their unique fit in the world, and when they identify what they are trying to accomplish in their lives (Steger, 2009a). Meaning systems liberally borrow values from cultural beliefs and worldviews, as well as personal attitudes (Steger, 2012). According to Emmons, people's lives draw meaning from multiple sources (as cited at Baumeister \& Vohs, 2002), and relationships with others have emerged as the most important source of meaning (Steger, 2009b). Meaning creation is linked to individual development and is likely to unfold in conjunction with other processes, such as the development of identity, relationships, and goals. The important finding is that caring about how one's self is defined within the society is part of having a meaningful life (Baumeister, Vohs, Aaker \& Garbinsky, 2013).

It has been suggested that national identity relates to psychological well-being and adjustment. Across different cultural groups, a strong sense of national identity has been repeatedly found to be associated with enhanced levels of well-being (Smith \& Silva, 2011; Dimitrova, Buzea, Ljujic \& Jordanov, 2013); with adaptive psychosocial functioning (Schwartz, Zamboanga, Wiesskirch, \& Rodriguez, 2009); and there is the finding (Reeskens \& Wright, 2010) that identification with one's nation-state fosters subjective well-being, which only applies for civic nationalists. On the other hand, the relationship between national identity and meaning in life has rarely been examined. Thus, the issue of this study is to examine the relationship between national identity, subjective well-being and meaning in life, assuming that the students with higher national identity would have higher subjective well-being (higher satisfaction with life, more positive affects and less negative affects) and higher meaning in life; contrary to the students with lower national identity who would have lower subjective well-being (lower satisfaction with life, less positive affects and more negative affects) and lower meaning in life.

\section{METHOD}

\section{Participants and procedure}

The sample consisted of 204 undergraduate students, 146 female and 58 male students at the age of 18 to 23 years $(M$ age $=19.18$ years, $S D=.96)$. The participants were students at various departments (Psychology, Sociology, Biology, Computer Sciences and Engineering) at the University of Ss Cyril and Methodius 
and MIT University in Skopje. The majority of the participants were Macedonians (83.8\%), but the sample also included Albanians (6.1\%), Turks $(5.6 \%)$ and others $(4.5 \%)$. After being informed about the general goal of the study and the confidentiality of personal data, the participants who wanted to take part in the research filled in the questionnaires. The data was collected in December 2014. Less than 3\% of the questionnaires were excluded due to more than one missed answer or obvious response set. The analysis was done on the whole sample, since the percentage of minorities in the sample was very low. The data was analyzed with SPSS 20.0.

\section{Measures}

The National Identity Scale (NIS; Čorkalo \& Kamenov, 2003) contains 27 items and four components or subscales: National Pride, Exclusive National Belonging (Nationalism), National Devotion and Cosmopolitanism. The items were rated on a 5-point Likert-like scale, ranging from 5-strongly agree to 1-strongly disagree. The general score was computed as a sum of all items and scores could range from 27 to 135 . A higher score indicated stronger national identity. Cronbach alpha reliability was .95 .

The Meaning in Life Questionnaire (MIL; Steger et al., 2006) is a 10-item scale, which contains two subscales, Presence of Meaning and Search for Meaning, each consisting of five items (for the needs of this study, Presence of Meaning was the only subscale used). The items were rated on a 7-point Likert-like scale ranging from 1-absolutely untrue to 7-absolutely true, and thus the scores could range from 7 to 35 on each subscale. The alpha coefficients in this sample were .88 for both subscales (Steger et al., 2006).

Subjective well-being is defined as life satisfaction, feeling more positive emotions and feeling less negative emotions (Diener, 1984). Based on the theoretical definition, SWLS and PANAS were used to measure subjective well-being. Subjective well-being was considered by the following formula: Subjective Well-being = (Satisfaction with Life + Positive Affects) - Negative Affects

The Satisfaction with Life Scale (SWLS; Diener, Emmons, Larsen, \& Griffin, 1985) consists of 5 items, which are rated on a 7-point Likert-like scale ranging from 1 -strongly agree to 7 -strongly disagree. The scores could range from 7 to 35 . The SWLS is among the most widely used well-being measures and numerous studies have confirmed its reliability and validity. Cronbach alpha reliability varied from .80 to .87 , test-retest stability .82 (Diener, Emmons, Larsen \& Griffin, 1985; Pavot \& Diener, 1993).

The Positive and Negative Affect Schedule (PANAS; Watson, Clark \& Tellegen, 1988) consists of two 10-item subscales that ask participants to rate the extent to which they experienced each affect. The first subscale assesses positive affect and the second one assesses negative affect. The items were rated from 1-very slightly 
or not at all to 5-extremely. The highest theoretical score for both subscales was 50 and the lowest score was 10. PANAS has been widely used and research has demonstrated very good internal consistency, test-retest stability, and structural validity. Crobach alpha reliability for PA was .87 and for NA it was .85 (Watson, Clark \& Tellegen, 1988; Watson \& Clark, 1994).

\section{RESULTS}

Mean scores and standard deviations of research variables were calculated and the findings are displayed at Table 1. According to these findings, the mean score for national identity is 80.48 ( $\mathrm{SD}=20.23$ ) which indicates a moderate expression of national identity. The mean score for presence of meaning in life is 26.39 $(S D=5.72)$ also indicating moderate expression of the presence of meaning in life. The mean score for subjective well-being which is a z-score is .00 $(S D=2.12)$ and it is moderate. The mean scores for the components of subjective well-being are: positive affects $M=35.42, S D=6.33$; negative affects $M=22.99, S D=7.49$; and sat-

Table 1. Descriptive Statistics for the Applied Measures

\begin{tabular}{lrrc}
\hline & \multicolumn{1}{c}{$M$} & \multicolumn{1}{c}{$S D$} & Theoretical range \\
\hline National identity & 80.48 & 20.23 & $27-135$ \\
Presence of meaning in life & 26.39 & 5.72 & $7-35$ \\
Subjective well-being & .00 & 2.12 & \\
Positive affects & 35.42 & 6.33 & $10-50$ \\
Negative affects & 22.99 & 7.49 & $10-50$ \\
Satisfaction with life & 22.99 & 6.46 & $7-35$ \\
\hline
\end{tabular}

Table 2. Correlations among Measures

\begin{tabular}{lllllll}
\hline & 1 & 2 & 3 & 4 & 5 & 6 \\
\hline (1) National identity & - & & & & & \\
(2) Presence of meaning in life & $.260^{* *}$ & - & & & & \\
(3) Subjective well-being & .094 & $.455^{* *}$ & - & & & \\
(4) Positive affects & -.032 & $.330^{* *}$ & $.671^{* *}$ & - & & \\
(5) Negative affects & -.089 & $.212^{* *}$ & $.725^{* *}$ & $.210^{* *}$ & - & \\
(6) Satisfaction with life & $.142^{*}$ & $.423^{* *}$ & $.728^{* *}$ & $.215^{* *}$ & $.331^{* *}$ & - \\
\hline
\end{tabular}

** Correlation is significant at the .01 level.

* Correlation is significant at the .05 level. 
isfaction with life $M=22.99, S D=6.46$. As we can notice, the scores are somewhat higher than the mean value of the scales, except the mean score of negative affects which is lower.

The relationships between each dimension were estimated with the Pearson Product Moment Correlation Coefficient (see Table 2). According to the findings, there was a low positive but statistically significant correlation between national identity and the presence of meaning in life $(r=.260, n=204, p<.01)$. There was no statistically significant correlation between national identity and subjective wellbeing, but a low statistically significant correlation was found between national identity and the cognitive aspect of subjective well-being, or satisfaction with life $(r=.142, n=204, p<.05)$.

\section{DISCUSSION}

The concept of national identity is both complex and highly abstract. The aim of this study was to examine the relationship between national identity, subjective well-being and meaning in life. The findings indicated that those with stronger national identity have higher meaning in life, but this stronger sense of national identity was not associated with higher levels of subjective well-being. However, the results showed that a strong sense of national identity is only associated with the cognitive aspect of subjective well-being, or satisfaction with life.

The positive relationship between national identity and the presence of meaning in life can be explained through the fact that human beings are the only creatures who have awareness of meaning in life. Meaning in life can be described by answering the questions "Who am I?" and "What am I living for?" Each of us could easily define their nation, feel attachment to it, and although our nation is an imagined community, we could easily recognize our language, culture, traditional values, customs, common name and so on (Čorkalo \& Kamenov, 2003). This identification may also be a way of interacting with others who share the same values and goals, providing the reference group with orientation and shared activity (Deaux, 2001). In this way we simply know who we are and who we are not, and through this sentimental identification with the nation individuals transcend their finite and, at least for some, meaningless lives (Guibernau, 2004). The findings about the relationship between national identity and subjective well-being are partly consistent with the results in the relevant literature. This might be happening because the concern with identity issues presumably affects the forming of the self, and such issues may arise especially during difficult times, which might account for any negativity towards happiness (Baumeister, Vohs, Aaker \& Garbinsky, 2013). Moreover, there are reasons to suspect that national identity may serve different psychological functions because of the social dynamics relevant to the majority and minority groups (Tajfel \& Turner, 1986). 
To sum up, the above data seems to support Nielsen's (1998) conclusion that we are lost if we cannot identify ourselves with some part of an objective social reality: a nation, though not necessarily a state, with its distinctive traditions. What we find in people is the need, not only to be able to say what they can do, but to say who they are.

There are several limitations to this study which should be addressed in future work in this area. First, the results could not be generalized to a broader population, due to the nature of the sample. Second, moderating and mediating variables, such as the need to belong, were not considered in the study. Third, factors such as perceived threat towards minority groups, experienced interethnic conflict and national campaigns, that are conducted by the government and the mass-media in order to reaffirm national identity and national pride, may also be linked to the national identification processes and should be considered in the future researches.

However, this study represents merely a first, yet important, step in understanding the relationship between national identity, meaning in life and subjective wellbeing, which confirms that the concept of national identity is a relevant phenomenon in the field of social and positive psychology.

\section{REFERENCES}

Baumeister, R. F., \& Vohs, K. D. (2002). The pursuit of meaningfulness in life. In C. R. Snyder \& S. J. Lopez (Eds.), The Handbook of Positive Psychology (pp. 608-618). Oxford: University Press, Inc.

Baumeister, R. F., Vohs, K. D., Aaker, J. L., \& Garbinsky, E. N. (2013). Some key differences between a happy life and a meaningful life. Journal of Positive Psychology, 8(6), 505-516.

Brewer, M. B. (1993). Social identity, distinctiveness, and in-group homogeneity. Social Cognition, 11(1), 150-164.

Čorkalo, D., \& Kamenov, Ž. (2003). National identity and social distance: Does in-group loyalty lead to out-grouphostility? Review of Psychology, 10(2), 85-94.

Deaux, K. (2001). Social identity. In J. Worrell (Ed.), Encyclopedia of Women and Gender (Vol. 2, pp. 1059-1067). San Diego, CA: Academic Press.

Diener, E. (1984). Subjective well-being. Psychological Bulletin, 95(3),542-575.

Diener, E., Emmons, R. A., Larsen, R. J., \& Griffin, S. (1985).The satisfaction with lifescale. Journal of PersonalityAssessment, 49(1),71-75.

Diener, E., Lucas, R. E. \& Oishi, S. (2002). Subjectivewell-being. The science of happiness and lifesatisfaction. In C. R. Snyder \& S. L. Lopes (Eds.), Handbook of Positive Psycho$\log y$ (pp. 63-73). Oxford: University Press, Inc.

Dimitrova, R., Buzea, C., Ljujic, V., \& Jordanov, V. (2013). The influence of nationalism and national identity on well-being of Bulgarian and Romanian youth. Studia Sociologica Special Issue on Identity and Nationalism in Cross-National Context, 8, 69-86. 
Guibernau, M. (2004). Anthony D. Smith on Nations and National identity: A Critical Assessment. Nations and Nationalism, 10(1/2), 125-141.

Myers, D. G., \& Diener, E. (1995). Who is happy?Psychological Science, 6(1), 10-19.

Nielsen, K. (1998). Liberal Nationalism, Liberal Democracies and Secession. University of Toronto Law Journal, 48(2), 253-295.

Pavot, W., \& Diener, E. (1993). Review of the Satisfaction with life scale. Psychological Assessment, 5(2), 164-172.

Reeskens. T., \& Wright, M. (2010). Subjective well-being and national satisfaction: Taking seriously the "proud of what?" question. Psychological Science, 22(11), 1460-1462.

Schwartz, S. J., Zamboanga, B. L., Weisskirch, R. S., \& Rodriguez, L. (2009). The relationships of personal and ethnic identity exploration to indices of adaptive and maladaptive psychosocial functioning. International Journal of Behavioral Development,33(2), 131-144.

Smith, A. (1992). National identity and the idea of European Unity. International Affairs, 68(1), 55-76.

Smith, T.B., \& Silva, L. (2011). Ethnic identity and personal well-being of people of color: A meta-analysis. Journal of Counseling Psychology, 58, 42-60.

Steger, M. F., Frazier, P., Oishi, S., \& Kaler, M. (2006). The Meaning in Life Questionnaire: Assessing the presence of and search for meaning in life. Journal of Counseling Psychology, 53(1), 80-93.

Steger, M. F. (2009a). Meaning in life. In S. J. Lopez (Ed.), Oxford Handbook of Positive Psychology (2 ${ }^{\text {nd }}$ Ed, pp. 679-687). Oxford, UK: Oxford University Press.

Steger, M. F. (2009b). Meaning in life. In S. J. Lopez (Ed.), Encyclopedia of Positive Psycho$\operatorname{logy}$ (Vol. 2, pp.605-610). Chichester: Blackwell Publishing, Ltd.

Steger, M. F. (2012). Making meaning in life. Psychological Inquiry, 23, 381-385.

Tajfel, H., \& Turner, J. C. (1986). The social identity theory of intergroup behavior. In S. Worchel \& W. G. Austin (Eds.), Psychology of intergroup relations (2nd ed., pp. 7-24). Chicago: Nelson-Hall.

Watson, D., Clark, L. A., \& Tellegen, A. (1988). Development and validation of brief measures of positive and negative affect: The PANAS scales. Journal of Personality and Social Psychology, 54(6),1063-1070.

Watson, D., \& Clark, L. A. (1994). The PANAS-X: Manual for the positive and negative affect schedule - Expanded form. The University of Iowa. 


\title{
POVEZANOST NACIONALNOG IDENTITETA, SUBJEKTIVNA DOBROBIT I SMISAO ŽIVOTA
}

\begin{abstract}
Sažetak
Studije su pokazale jaku vezu između nacionalnog identiteta i nekih od konstrukta pozitivne psihologije. Do sada, ove teme su bile vrlo rijetko istraživane u makedonskom kontekstu. Cilj ovog istraživanja je bio utvrditi odnos između nacionalnog identiteta, subjektivne dobrobiti i smisla života. Dakle, 204 dodiplomska studenta su sudjelovala u istraživanju, 146 žena i 58 muškaraca u dobi od 18 do 23 godine. Za prikupljanje podataka primijenjene su: Skala nacionalnog identiteta (NIS) kao mjera nacionalnog identiteta, smisao života bio je mjeren Upitnikom o smislu života (MIQ); za mjerenje kognitivnih aspekata subjektivne dobrobiti je korištena Skala zadovoljstva životom (SWLS); dok je afektivan aspekt mjeren Ljestvicom pozitivnog i negativnog afekta (PANAS). Pretpostavlja se da će studenti s izraženijim nacionalnim identitetom imati veće zadovoljstvo životom, pozitivniji su i imaju viši smisao života, za razliku od studenata s manje izraženim nacionalnim identitetom, koji će imati manje zadovoljstvo životom, negativniji su i imaju manji smisao života. Veze između svake dimenzije procijenjene su Pearsonovim koeficijentom korelacije, a rezultati su djelomično potvrdili predviđanja. Nađena je pozitivna korelacija između nacionalnog identiteta, zadovoljstva životom i prisutnosti smisla života. Nije pronađena povezanost između nacionalnog identiteta i afektivnog (pozitivnog i negativnog) aspekta subjektivne dobrobiti. Ovi rezultati su važni jer daju novi uvid u odnose konstrukata nacionalnog identiteta $i$ konstrukta pozitivne psihologije, smisla života i aspekta subjektivne dobrobiti.
\end{abstract}

Ključne riječi: nacionalni identitet, subjektivna dobrobit, smisao života

Prihvaćeno za tisak: 07. 09. 2016. 
